\title{
IT GOVERNANCE, IT SERVICE MANAGEMENT AND THE ORGANIZING ROLE OF THE INFORMATION TECHNOLOGY INFRASTRUCTURE LIBRARY (ITIL)
}

\author{
Barbara Jo White, Western Carolina University, whiteb@email.wcu.edu
}

\begin{abstract}
A gap exists between IT management topics important to CIOs and topics present in typical MIS texts. One way to bridge that gap and synchronize IT management knowledge between students, academics and CIOs is through the use of IT governance frameworks to organize introductory undergraduate MIS courses. The use of the Information Technology Infrastructure Library (ITIL) IT Service Management framework (version 2) is presented as a course organizing framework for both undergraduate business courses and upper level IS/IT courses for non-MIS majors. Student reaction is discussed.
\end{abstract}

Keywords: IT Governance, Information Technology Infrastructure Library (ITIL), COBIT

\section{INTRODUCTION}

Synchronizing knowledge between academics and IT professionals is important if we are to give our students the skills to succeed in industry. One area in need of greater synchronization is that of IT management topics. Most colleges of business have a course that all students must take that is typically called "Management Information Systems" (MIS).

There appears to be a gap between IT management topics important to CIOs and topics present in typical MIS texts. One way to bridge that gap and synchronize IT management knowledge between academics and CIOs is through the use of IT governance frameworks as a way to organize typical introductory undergraduate MIS courses. IT Governance refers to "the leadership and organizational structures and processes to ensure that the organization's IT sustains and extends the organization's strategy and objectives” [18, p. 10].

This paper describes the misalignment between academics and IT professionals regarding management priorities and uses an IT governance framework to bridge the gap. Specifically, the Information Technology Infrastructure Library (ITIL) [27] is used as a course-organizing framework for two courses: an undergraduate introductory MIS course; and an upper-level IS/IT course for non-MIS majors. Student reaction to the courses is discussed.

\section{THE MISALIGNMENT BETWEEN CIO AND ACADEMIC IT MANAGEMENT PRIORITIES}

\section{Understanding CIO Priorities}

Gartner Research conducts annual surveys $[9,10,11$, $12,13,14,15,16]$ of CIO professionals listing their top ten business and technology priorities (see Appendix) as well as their top ten strategic management priorities (see Table 1).

Table1: Top Ten Strategic Management Priorities for CIOs 2004-2007 [9, 10, 12, 14, 15, 16]

\begin{tabular}{|c|c|c|c|c|}
\hline $\begin{array}{l}\text { To what extent will each } \\
\text { of the following CIO } \\
\text { actions be a priority for } \\
\text { you in 2006? }\end{array}$ & '07 & '06 & '05 & '04 \\
\hline $\begin{array}{l}\text { Delivering projects that } \\
\text { enable business growth }\end{array}$ & 1 & 1 & 1 & 18 \\
\hline $\begin{array}{l}\text { Linking business and IT } \\
\text { strategies and plans }\end{array}$ & 2 & 2 & 2 & 4 \\
\hline $\begin{array}{l}\text { Improving the quality of } \\
\text { IS service delivery }\end{array}$ & 3 & 7 & 7 & 3 \\
\hline $\begin{array}{l}\text { Attracting, developing } \\
\text { and retaining IS } \\
\text { personnel }\end{array}$ & 4 & 5 & & \\
\hline $\begin{array}{l}\text { Demonstrating the } \\
\text { business value of IT }\end{array}$ & 5 & 4 & 3 & 2 \\
\hline $\begin{array}{l}\text { Providing new types of } \\
\text { information (analytics) }\end{array}$ & 6 & & & \\
\hline $\begin{array}{l}\text { Developing or managing } \\
\text { a flexible technology } \\
\text { infrastructure }\end{array}$ & 7 & 8 & & \\
\hline $\begin{array}{l}\text { Improving IT } \\
\text { governance }\end{array}$ & 8 & 9 & 10 & 11 \\
\hline $\begin{array}{l}\text { Building business skills } \\
\text { in the IS organization }\end{array}$ & 9 & 3 & 9 & 1 \\
\hline $\begin{array}{l}\text { Leading change } \\
\text { initiatives (involving } \\
\text { more than IT) }\end{array}$ & 10 & & & \\
\hline $\begin{array}{l}\text { Applying metrics to the } \\
\text { IS organization and IT } \\
\text { services }\end{array}$ & & 6 & 4 & 14 \\
\hline $\begin{array}{l}\text { Consolidating the IS } \\
\text { organization and } \\
\text { operations }\end{array}$ & & 10 & 8 & \\
\hline
\end{tabular}


This information is crucial if we are to understand current practice. "Improving IT governance" made the list of Gartner's top ten CIO strategic management priorities in 2003 [13], has stayed on the list since and has risen in importance since 2004 [10]. A 2007 survey of CIOs [12] lists "Improving IT governance" as one of the top five strategies CIOs expect to address in the next year. Clearly, IT governance is on the minds of CIOs.

CIOs, however, aren't the only ones talking about IT governance. IT professionals at all levels are involved. For example, as part of its Operational Excellence program, nearly 1000 state employees from various agencies in North Carolina have completed IT governance training. Specifically, North Carolina has sponsored subsidized FoundationLevel certificate training in ITIL. Foundation-level training, however, is available through a variety of training organizations worldwide.

\section{Understanding Typical MIS Course Priorities}

Basic Management Information Systems textbooks seem to cover topics more aligned with the technology priorities of CIOs (see Appendix). A selection of four texts [2, 20, 22, 25] shows many similarities in the topics they cover (see Table 2).

Most texts do cover topics relating to the technology and business priorities of CIOs (see Appendix). However, the same texts either don't seem to cover the strategic management priorities at all or don't cover them very well.

Concerning "IT governance," for example, only one of the four texts [25] listed even mentions the term at all. The O'Brien text [25] manages, in a 628-page book, to mention "IT governance" in one lengthy sentence:

Involving managers in the management of IT (from the CEO to the managers of business units) requires the development of governance structures (such as executive councils and steering committees) that encourage their active participation in planning and controlling the business uses of IT. (p. 550).

Given the differences between what CIOs think is important, from a strategic management perspective, and what the textbooks emphasize, there is an opportunity for IT governance frameworks to bridge that gap. IT governance frameworks can provide a different type of organizational structure to undergraduate MIS courses for various populations.
Table 2: Topics Covered in Common MIS Textbooks $[2,20,22,25]$

\begin{tabular}{|c|c|c|c|c|}
\hline Topic & $\begin{array}{c}\text { Laudon } \\
\& \\
\text { Laudon } \\
\text { [22] } \\
\end{array}$ & $\begin{array}{c}\text { O'Brien } \\
\& \\
\text { Marakas } \\
{[25]} \\
\end{array}$ & $\begin{array}{c}\text { Jessup } \\
\& \\
\text { Valacich } \\
{[20]} \\
\end{array}$ & $\begin{array}{c}\text { Baltzan } \\
\& \\
\text { Phillips } \\
\text { [2] } \\
\end{array}$ \\
\hline $\begin{array}{l}\text { Info Systems } \\
\text { in (Global) } \\
\text { Business }\end{array}$ & 1 & 1 & 1 & 1 \\
\hline Hardware & 5 & 3 & A1 & 5 \\
\hline Software & 5 & 4 & A2 & 5 \\
\hline $\begin{array}{l}\text { Business } \\
\text { Processes and } \\
\text { IS }\end{array}$ & 2 & 7 & 2 & \\
\hline $\begin{array}{l}\text { Competitive } \\
\text { Advantage } \\
\text { with IT; } \\
\text { Value Chain; } \\
5 \text { Forces }\end{array}$ & 3 & 2 & 3 & 1 \\
\hline $\begin{array}{l}\text { Ethical and } \\
\text { Social Issues }\end{array}$ & 4 & 13 & 10 & 4 \\
\hline IT Security & 8 & 13 & 6 & 4 \\
\hline $\begin{array}{l}\text { BI: Databases } \\
\text { and Data } \\
\text { Mining }\end{array}$ & 6 & 5 & 3 & 6 \\
\hline $\begin{array}{l}\text { Networks \& } \\
\text { Telecommun- } \\
\text { ications }\end{array}$ & 7 & 6 & $\begin{array}{c}4, \\
\mathrm{~A} 4, \mathrm{~A} 5\end{array}$ & 7 \\
\hline $\begin{array}{l}\text { Supply Chain } \\
\text { Mgmt. }\end{array}$ & 9 & 8 & 8 & 8 \\
\hline $\begin{array}{l}\text { Customer } \\
\text { Relationship } \\
\text { Mgmt. }\end{array}$ & 9 & 8 & 8 & 9 \\
\hline $\begin{array}{l}\text { Enterprise } \\
\text { Resource } \\
\text { Planning }\end{array}$ & ? & 8 & 8 & 10 \\
\hline $\begin{array}{l}\text { E-Commerce } \\
\text { and E- } \\
\text { Business }\end{array}$ & 10 & 9 & 5 & 3 \\
\hline $\begin{array}{l}\text { AI, Gen. Alg., } \\
\text { KM, Expert } \\
\text { Sys., Neural } \\
\text { Nets }\end{array}$ & 11 & 10 & 7 & 2 \\
\hline $\begin{array}{l}\text { DSS, ESS, } \\
\text { GDSS, EIS }\end{array}$ & 12 & 10 & 7 & 2 \\
\hline $\begin{array}{l}\text { Developing } \\
\text { IT Systems }\end{array}$ & 13 & 12 & 9, A3 & 11 \\
\hline $\begin{array}{l}\text { Proj. Mgmt: } \\
\text { Bus. Value of } \\
\text { IT; Imple- } \\
\text { mentation }\end{array}$ & 14 & 7 & & 12 \\
\hline $\begin{array}{l}\text { Managing } \\
\text { Global IT; } \\
\text { Sourcing }\end{array}$ & 15 & 14 & 2 & 12 \\
\hline
\end{tabular}


While “internally-developed” IT governance frameworks were most popular in 2005, firms now turn to recognized frameworks and tools such as ITIL/ISO 20000 and CobiT [ITGI].

The next section discusses a variety of IT governance tools, including the three popular IT governance tools: ITIL, CobiT, and ISO 20000.

\section{UNDERSTANDING IT GOVERNANCE AND IT GOVERNANCE TOOLS USED BY CIOs}

There is a lack of clarity regarding the definition of IT Governance. Simonsson [31] analyzed the various definitions of IT governance and proposed the following:

IT governance is the preparation for, making of and implementation of IT-related decisions regarding goals, processes, people and technology on a tactical or strategic level. (p. 18).

Other researchers adopt the definition of IT governance provided by the IT Governance Institute [18]:

IT governance is the responsibility of the Board of Directors and executive management. It is an integral part of executive management and consists of the leadership and organizational structures and processes to ensure that the organisation's IT sustains and extends the organisation's strategy and objectives.(p. 10).

Besides disagreement regarding the definition of $I T$ governance, there is also some disagreement about what qualifies as an IT governance tool. For example, one review [17] includes the following 17 IT governance tools: ITIL, Control Objectives for Information and Related Technology (CobiT), ASL, Six Sigma, Capability Maturity Model (CMM), IT Service CMM, Statement on Auditing Standards (SAS70), ISO 17799, Sarbanes-Oxley Act of 2002, SysTrust, PRINCE2, IT Audit, IT Due Diligence, IT Governance Review, IT Governance Assessment, IT Governance Checklist, and IT Governance Assessment Process (ITGAP). These tools can be differentiated according to the type of processes they deal with as well as organizational entity involved [17] as shown in Figure 1.

However, while ITIL is classified as an IT governance tool above [17], the IT Governance Institute [19] argues that "ITIL is focused mainly on service delivery and is not an IT governance framework" (p. 36).

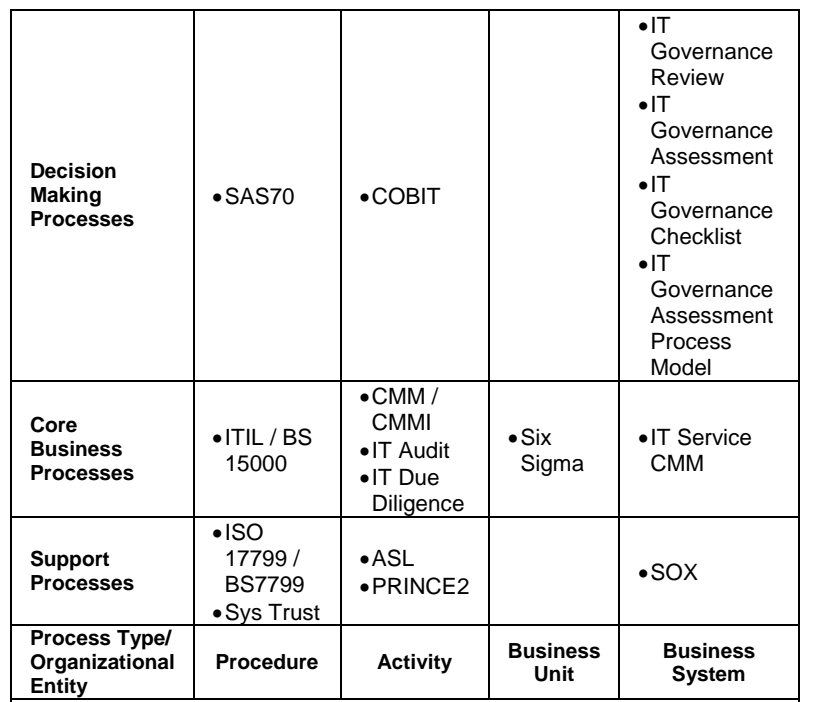

Figure 1: Classification of IT Governance Tools [17]

Others also agree [28] that ITIL is a form of IT management which differs from IT governance in significant ways. Principally, Sallé [28] argues that IT governance is more future-oriented and external, while IT management, including ITIL, is more internal to the organization and present-oriented.

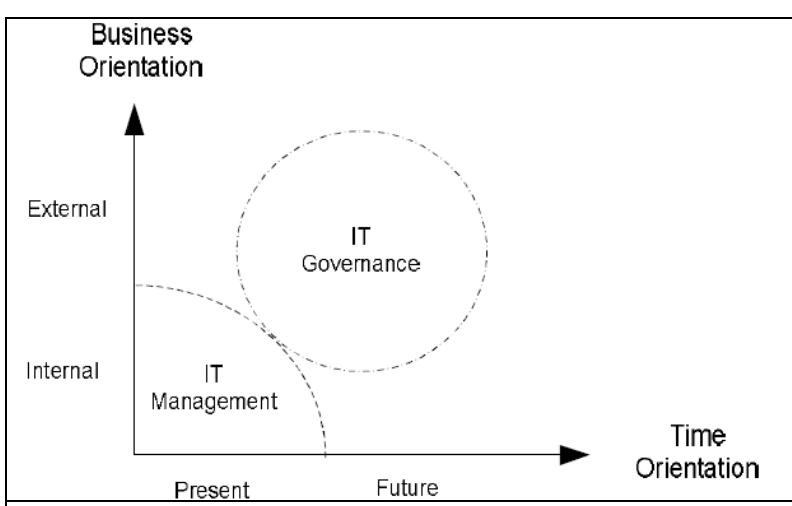

Figure 2: IT Governance vs IT Management [28]

The following section describes ITIL and two other very popular IT governance tools -- CobiT and ISO 20000.

\section{Control Objectives for Information and Related Technology (CobiT)}

The IT Governance Institute developed and promotes CobiT as the de facto IT governance tool. CobiT is defined below [28]:

CobiT third edition consists of an Executive Summary highlighting CobiT main benefits, $a$ business oriented framework covering all IT activities, a set of management guidelines enabling management to align IT activities 
and priorities with business requirements, 318 detailed control objectives, a set of audit guidelines and an implementation tool set.(p. 4)

Specifically, CobiT defines 34 IT processes grouped into the following four domains: planning \& organization; acquisition \& implementation; delivery \& support; and monitoring [28].

\section{ISO 17799 and ISO 20000}

The International Organization for Standardization's ISO 17799 covers ten categories of security measurement practices [17]. ISO 20000 covers areas associated with IT Service Management.

\section{Information Technology Infrastructure Library (ITIL)}

ITIL was developed in the 1980s by the British organization OGC and is a framework of best practices in IT Service Management. Version 2 of ITIL is organized into seven major areas [27] as shown in Figure 3 below:

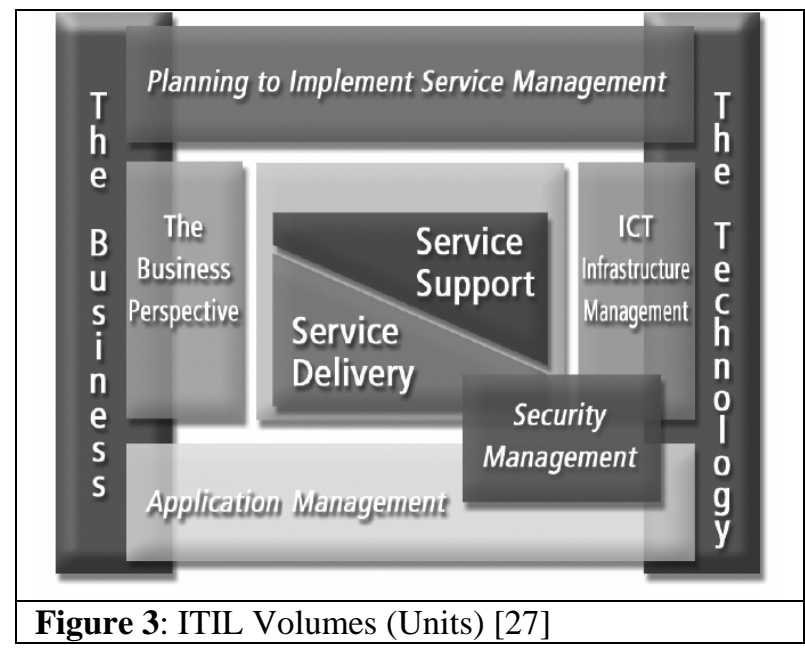

The seven units, or volumes, are defined as follows:

Service Delivery: covers the strategic processes associated with planning and delivery of quality IT services [27];

Service Support: involves processes associated with daily support and maintenance activities [27];

Information and Communications Technology (ICT) Infrastructure Management: covers all processes from the identification of business requirements through testing, implementation and operation of ICT components [27];
Planning to Implement Service Management: covers project-management type processes related to organisational change and planning, implementing and improving service management [27];

Application Management: involves processes throughout the application lifecycle [27];

The Business Perspective: describes processes concerned with ways IT personnel can better align their roles and services with the organization to better achieve business objectives [27]; and

Security Management: covers processes associated with risk identification and management and security of IT services [27].

In ITGI's recent 2008 Global Status Report [19], ITIL (and ISO 20000) were the most popular frameworks. Furthermore, over $20 \%$ of the firms surveyed were either using or planning to use ITIL [19].

The next section describes the use of the seven ITIL units as a way to organize two MIS courses which results in a greater alignment with CIO strategic management priorities of IT governance.

\section{USING THE ITIL FRAMEWORK TO ORGANIZE MIS COURSES}

Across both undergraduate courses, the seven volumes in the ITIL library were used to structure units. Though the version of ITIL described here is officially known as ITIL V2, the material has only very recently been reorganized in a third version (V3). The ITIL V3 format resembles the systems development lifecycle with five new groupings of service strategy, service design, service transition, and service operation and continual service improvement (www.itil-officialsite.com). The ITIL V2 units were used for two courses: a core business course for all business majors and an upper level liberal studies course aimed at criminal justice students.

\section{ITIL Framework In A Core Business Course}

Most Colleges of Business have a course in MIS that all business majors take, regardless of their particular major. From student surveys at the beginning of the course, students entered the course either with very little knowledge about what the IT department does or with the general idea that the IT department provides a help desk function and fixes their computers: 
The IT department has something to do with fixing computers and making sure that the operating systems are running the way they should be; I don't know.

The course included the seven units corresponding to the ITIL volumes with appropriate chapters from an MIS textbook [2].

The Business Perspective: A natural starting point, this unit covered an overview of the course as well as aspects of competitive advantage and the business value of IT.

Planning to Implement Service Management: This unit covered areas related to project management as well as the marketing areas of services as products.

Service Delivery: This unit covered the strategic processes associated with planning and delivery of quality IT services.

Service Support: This unit involved staffing and roles in the IT/IS department as well as issues associated with communication between IT staff and employees.

Information and Communications Technology (ICT) Infrastructure Management: This unit covered aspects of hardware, software and networks including data/voice convergence.

Security Management: This unit covered topics such as IT security and IT ethics and social issues.

Application Management: This unit covered types of information systems, database development lifecycle and data mining.

The semester-long project in this course was an investigation of IT in student careers. Students produced a report (written paper) and gave a presentation of their findings. First, students first investigated careers their major would lead to using career information websites [26]. In particular, students paid attention to tools and technologies used in these careers. Then, students used various job search engines to find jobs they were interested in. Having gathered this information, students compared whether tools and technologies, if mentioned in the job descriptions, correlated with what they learned about their careers from the career information websites [26]. Then, students investigated types of systems (Customer Relationship Management, Supply Chain Management, Enterprise Resource Planning, Decision Support Systems, etc.) used by firms and their industries. Students also imagined themselves working in a firm of their choosing and sitting on a software committee/task force charged with finding several vendors who provide software and services that would meet their department's needs.

For the presentation, students worked with others in similar functional areas or similar industries, integrated their findings, and created and gave a presentation.

While project surveys don't specifically mention ITIL, the organization around ITIL units appears to have helped students realize the strategic importance of IT compared to previous versions of the course. By the end of the semester, students were more aware of the notion that IT systems are strategic, and are used to gain a competitive advantage:

The IT department helps to maintain computers and helps make the business run smoother;

They ... work with the technology that you need for a business so you can have a competitive advantage.

Besides introductory MIS courses, ITIL units have also been used for general education (liberal studies) courses. The next section describes ITIL units in a liberal studies course.

\section{ITIL Framework In A General Education (Liberal Studies) Course}

There are many potential departments beyond the college of business whose students could benefit from a liberal studies MIS course. For example, criminal justice, social work, nursing and education departments may have students interested in a MIS course that could give them insights into their future workplaces. Criminal Justice faculty members were particularly receptive to collaborating on an online course designed for their students, many of whom work in law enforcement agencies. Faculty members from the Computer Information Systems department and from the Criminal Justice department met several times to discuss aspects of the proposed course. An upper-level MIS course was created in the social science liberal studies category. The online course focused on the social science area of organizations and organizational behavior.

The course, "Issues in Public Safety Information Systems," was divided into the seven units suggested by the ITIL v2 Framework. Each week, readings included chapters from various MIS, management and marketing texts associated with the seven ITIL units. Weekly readings involving short journal 
articles, chiefly from a top journal in MIS, Communications of the ACM, included the following:

The Business Perspective unit included Carr's [4] provocative article “IT Doesn't Matter” and Avison's [1] article, "Managerial IT Unconsciousness.”

The ICT Infrastructure Management unit included articles on Centralization by Evaristo, Desouza, \& Hollister [8] as well as Schuff \& St. Louis [29].

Application Management: included articles following the evolution of COPLINK, a system used for analyzing and visualizing criminal networks, [5, 34] and the evolution of the FBI Trilogy software using audio files found on National Public Radio’s website.

The Security Management unit included articles covering security issues such as Whitman's [33] article describing information security threats facing businesses and Siponen's [32] article on information security standards.

The unit on Planning to Implement Service Management included Steven Kerr's [21] classic article "On the Folly of Rewarding A while Hoping for B.”

The Service Support unit included IS-User interaction articles such as such as Malhotra and Galleta's [23] article "Building Systems That Users Want to Use,” and Christopher Carr's [3] article on the relationship between users and IS staff.

The unit on Service Delivery included articles such as Muller's [24] article on service level agreement management and Smith, Schuff, and St. Louis' [6] article discussing the total cost of ownership of IT investments.

Weekly assignments for the online course included written assignments, which were designed to use the newly acquired vocabulary, and discussions of the associated articles above. There were also nondiscussion type activities for several of the units. For example, in the Service Delivery unit, students wrote a Service Level Agreement (SLA) for a service they provided through work or family life. One student wrote a SLA for his role in provision of "Dad" services. Students also, as part of the service delivery unit, examined the total cost of system ownership. Specifically, they suggested various ways in which the State of North Carolina Voice Interoperability Plan for Emergency Responders (VIPER) system could be charged back to county and state agencies using the system. The large project for the semester was a website analysis project. Students compared their own county or state agency websites with police department websites from various other U.S. cities and counties focusing on how law enforcement agencies use IT to provide services to citizens.

Reaction to the course, both anecdotally and from course evaluations, was extremely positive. Many students remarked how the course gave them a better understanding of their agency IT departments.

\section{CONCLUSIONS}

Many firms [19] will be using IT governance tools, such as ITIL, in order to provide better, and more efficient, IT service to their employees, or internal customers, in departments where our students might be working.

One reason firms are implementing ITIL practices is that they have already proven effective. For example, the North Carolina Office of IT Services (ITS), which has adapted and implemented ITIL service management practices as part of an Operational Excellence program, has achieved positive results. For example, ITS has seen a $200 \%$ increase in its ability to resolve incidents within service level agreements, a 200\% increase in its ability to plan changes ahead of time, a $20 \%$ increase in agency productivity and a $30 \%$ increase in service desk productivity. The North Carolina program has won two national ITIL Project of the Year awards from itSMF and Pink Elephant [30].

Using the ITIL volumes as course units not only provides a structure emphasizing the strategic nature of IT, but also gives students experience with realworld trends they are likely to see again in the workplace when they graduate.

\section{REFERENCES}

1. Avison, D., Gregor, S., \& Wilson, D. (2006) Managerial IT unconsciousness. Communications of the ACM, 49(7), 88-93.

2. Baltzan, P. \& Phillips, A. (2008). Business Driven Information Systems. Boston: McGrawHill Irwin.

3. Carr, C. L. (2006) Reciprocity: The golden rule of IS-user service relationship quality and cooperation. Communications of the ACM, 49(6), 77-83.

4. Carr, N. (2003). IT doesn't matter. Harvard Business Review, 81 (5), 41-49.

5. Chen, H., Atabakhsh, H., Wyzga, W., \& Schroeder, J. (2003) COPLINK: Managing law 
enforcement data and knowledge. Communications of the ACM, 46(1), 28-34.

6. David, J. S., Schuff, D., \& St. Louis., R. (2002). Managing your total IT cost of ownership. Communications of the ACM, 45(1), 101-106.

7. De Haes, S. \& Van Grembergen, W. (2004). IT governance and its mechanisms. Information Systems Control Journal, 1.

8. Evaristo, J. R., Desouza, K. C., \& Hollister, K. (2005). Centralization momentum: The pendulum swings back again. Communications of the ACM, 48(2), 66-71.

9. Gartner. (2006). Growing IT's contribution: The 2006 CIO Agenda. Gartner EXP Premier.

10. Gartner. (2007). Creating enterprise leverage: The 2007 CIO Agenda. Gartner EXP Premier.

11. Gartner. (2008). Making the difference: The 2008 CIO Agenda. Gartner EXP Premier. Gartner. (2007). Gartner EXP Survey of More than 1,400 CIOs Shows CIOs Must Create Leverage to Remain Relevant to the Business. Gartner Press Release. Available: www.gartner.com/it/page.jsp?id=501189

12. Gartner. (2008). Gartner EXP Worldwide Survey of 1,500 CIOs Shows 85 Percent of CIOs Expect "Significant Change" Over Next Three Years. Gartner Press Release. Available: www.gartner.com/it/page.jsp?id=587309

13. Gartner. (2005). Gartner Survey of 1,300 CIOs Shows IT Budgets to Increase by 2.5 Percent in 2005. Gartner Press Release. Available: www.gartner.com/press_releases/asset_117739_ 11.html

14. Gartner. (2006). Gartner Survey of 1,400 CIOs Shows Transformation of IT Organisation is Accelerating. Gartner Press Release. Available: www.gartner.com/press_releases/asset_143678_ 11.html

15. Gartner: IT budgets to rise by seven percent (2005, April). Network Magazine India. Available:

www.networkmagazineindia.com/200504/newsa nalysis03.shtml

16. Holm Larsen, M., Kühn Pedersen, M., \& Viborg Andersen, K. (2006). IT Governance: Reviewing 17 IT Governance Tools and Analysing the Case of Novozymes A/S, Proceedings of the 39th Hawaii International Conference on system Sciences (HICCSS’06) Track 8.

17. IT Governance Institute (2003). Board Briefing on IT Governance, $2^{\text {nd }}$ ed. Available: www.itgi.org.

18. IT Governance Institute, (2008). IT Governance Global Status Report-2008. Available: www.itgi.org.
19. Jessup, L. \& Valacich, J. (2008). Information Systems Today: Managing in the Digital World, $3^{\text {rd }}$ ed. New Jersey, Person Education.

20. Kerr, S. (1975). On the folly of rewarding A while hoping for B. Academy of Management Journal, 18, 769-783.

21. Laudon, K. \& Laudon, J. (2007). Management Information Systems: Managing the Digital Firm, $10^{\text {th }}$ ed. New Jersey: Pearson Education.

22. Malhotra, Y., and Galletta, D. (2004) Building systems users want to use. Communications of the ACM, 47(12), 88-94.

23. Muller, N. J. (1999) Managing service level agreements. International Journal of Network Management, 9(3), 155-166.

24. O’Brien, J. \& Marakas, G. (2008). Management Information Systems, $8^{\text {th }}$ ed. Boston: McGrawHill/Irwin.

25. Occupational Information Network. Welcome to O*Net Online! Available: online.onetcenter.org.

26. Rudd, C. (2004). An Introductory Overview of ITIL. UK-itSMF.

27. Sallé, M. (2004). IT service management and IT governance: Review, comparative analysis and their impact on utility computing. HPL-2004-98. Hewlett-Packard Company.

28. Schuff, D., \& St. Louis, R. (2001) Centralization vs. decentralization of application software. Communications of the ACM, 44(6), 88-94.

29. State Chief Information Officer. Statewide IT Awards. Available: www.scio.state.nc.us/awards.asp

30. Simonsson, M., \& Ekstedt, M. (2006). Getting the priorities right: Literature vs practice on IT governance, Proceedings of Portland International Center for Management of Engineering Technology Conference, 18-23.

31. Siponen, M. (2003) Information security standards focus on the existence of process, not its contents. Communications of the ACM, 49(8), 97-100.

32. Whitman, M. (2003) Enemy at the gate: Threats to information. Communications of the ACM, 46(8), 91-95.

33. Xu, J., \& Chen, H. (2005) Criminal network analysis and visualization. Communications of the ACM, 48(6), 100-107. 
Appendix

Top 10 Business Priorities 2005-2008

$[9,10,11,12,13,14,15,16]$

\begin{tabular}{|c|c|c|c|c|}
\hline & '08 & ${ }^{\prime} 07^{\circ}$ & ${ }^{\prime} 06^{+}$ & '05 \\
\hline $\begin{array}{l}\text { Improving business } \\
\text { processes }\end{array}$ & 1 & 1 & 1 & 1 \\
\hline $\begin{array}{l}\text { Attracting and retaining } \\
\text { new customers }\end{array}$ & 2 & 3 & 3 & \\
\hline $\begin{array}{l}\text { Creating new products or } \\
\text { services (innovation); } \\
\text { Faster innovation (shorter } \\
\text { product/service life } \\
\text { cycles) }\end{array}$ & 3 & 10 & 9 & \\
\hline $\begin{array}{l}\text { Expanding into new } \\
\text { markets or geographies }\end{array}$ & 4 & 9 & & \\
\hline Reducing enterprise costs; & 5 & 2 & 2 & 3 \\
\hline $\begin{array}{l}\text { Improving enterprise } \\
\text { workforce effectiveness }\end{array}$ & 6 & 4 & & \\
\hline $\begin{array}{l}\text { Expanding current } \\
\text { customer relationships }\end{array}$ & 7 & & & \\
\hline $\begin{array}{l}\text { Increasing the use of } \\
\text { information / analytics; } \\
\text { expanding the use of } \\
\text { information/intelligence in } \\
\text { products and services }{ }^{\#}\end{array}$ & 8 & 7 & 6 & 7 \\
\hline $\begin{array}{l}\text { Targeting customers and } \\
\text { markets more effectively }\end{array}$ & 9 & & & \\
\hline $\begin{array}{l}\text { Acquiring new companies } \\
\text { and capabilities (mergers } \\
\text { and acquisitions) }\end{array}$ & 10 & & & \\
\hline $\begin{array}{l}\text { Revenue growth; Need for } \\
\text { revenue growth }\end{array}$ & & 5 & 8 & 6 \\
\hline $\begin{array}{l}\text { Improving } \\
\text { competitiveness; } \\
\text { improving enterprise } \\
\text { competitiveness (bottom } \\
\text { line profitability) }\end{array}$ & & 6 & 5 & \\
\hline $\begin{array}{l}\text { Improving competitive } \\
\text { advantage }^{+} \text {; supporting } \\
\text { competitive advantage }^{\#}\end{array}$ & & & 4 & 4 \\
\hline $\begin{array}{l}\text { Deploying new business } \\
\text { capabilities to meet } \\
\text { strategic goals }\end{array}$ & & 8 & & \\
\hline $\begin{array}{l}\text { Entering new markets, } \\
\text { new products or new } \\
\text { services }\end{array}$ & & 9 & & \\
\hline $\begin{array}{l}\text { Faster innovation and } \\
\text { cycle times }\end{array}$ & & & 10 & 10 \\
\hline $\begin{array}{l}\text { Security breaches and } \\
\text { disruptions }\end{array}$ & & & 7 & \\
\hline $\begin{array}{l}\text { Data protection and } \\
\text { privacy }\end{array}$ & & & & 5 \\
\hline Focus on internal controls & & & & 8 \\
\hline Shortage of business skills & & & & 9 \\
\hline
\end{tabular}

Top 10 Technology Priorities 2005-2008

$[9,10,11,12,13,14,15,16]$

\begin{tabular}{|c|c|c|c|c|}
\hline & '08 & ${ }^{\prime} 07^{\circ}$ & ' $06^{+}$ & ${ }^{\prime} 05^{\#}$ \\
\hline $\begin{array}{l}\text { Business Intelligence } \\
\text { applications }\end{array}$ & 1 & 1 & 1 & 2 \\
\hline $\begin{array}{l}\text { Enterprise applications } \\
\text { (ERP, CRM and others); } \\
\text { Enterprise resource } \\
\text { planning upgrades }\end{array}$ & 2 & 3 & & 5 \\
\hline $\begin{array}{l}\text { Customer relationship } \\
\text { management (CRM) }\end{array}$ & & & & 8 \\
\hline $\begin{array}{l}\text { Servers and storage } \\
\text { technologies; Servers } \\
\text { and storage technologies } \\
\text { (virtualization) }^{\circ} \text {; } \\
\text { virtualization }^{+} \text {; server } \\
\text { virtualization }^{\#}\end{array}$ & 3 & 5 & 9 & 10 \\
\hline Storage Management ${ }^{\#}$ & & & & 6 \\
\hline $\begin{array}{l}\text { Legacy modernization; } \\
\text { Legacy application } \\
\text { modernization }^{{ }^{+}} \text {; }\end{array}$ & 4 & 3 & 10 & \\
\hline Technical infrastructure & 5 & & & \\
\hline $\begin{array}{l}\text { Security technologies; } \\
\text { security enhancement } \\
\text { tools }\end{array}$ & 6 & 6 & 2 & 1 \\
\hline $\begin{array}{l}\text { Networking, voice and } \\
\text { data; Networking, voice } \\
\text { and data } \\
\text { communications }^{0+} \text {; } \\
\text { Voice and data } \\
\text { integration over } \mathrm{IP}^{\#}\end{array}$ & 7 & 4 & 8 & 7 \\
\hline $\begin{array}{l}\text { Collaboration } \\
\text { technologies }\end{array}$ & 8 & 10 & 4 & \\
\hline Document management & 9 & 9 & & \\
\hline $\begin{array}{l}\text { Service-oriented } \\
\text { architecture (SOA) and } \\
\text { service-oriented } \\
\text { business applications } \\
(\mathrm{SOBA}) \text {; Service- } \\
\text { oriented architectures }^{\mathrm{O}+} \text {; }\end{array}$ & 10 & 7 & 6 & \\
\hline $\begin{array}{l}\text { Technical infrastructure } \\
\text { management }\end{array}$ & & 8 & & \\
\hline $\begin{array}{l}\text { Mobile workforce } \\
\text { enablement }\end{array}$ & & & 3 & 3 \\
\hline $\begin{array}{l}\text { Customer sales and } \\
\text { service }\end{array}$ & & & 5 & \\
\hline $\begin{array}{l}\text { Workflow } \\
\text { management }{ }^{+} \text {; workflow } \\
\text { management } \\
\text { deployment and } \\
\text { integration }\end{array}$ & & & 7 & 4 \\
\hline $\begin{array}{l}\text { Business process } \\
\text { integration tools }\end{array}$ & & & & 9 \\
\hline
\end{tabular}

